\title{
Increased circulating cytokines in patients with myocarditis and cardiomyopathy
}

\author{
Akira Matsumori, Takehiko Yamada, Hiroshi Suzuki, Yoshiki Matoba,
} Shigetake Sasayama

\begin{abstract}
Objectives-To elucidate the potential role of cytokines in the pathogenesis of cardiomyopathy and myocarditis.

Background-Experimental studies show that certain cytokines depress myocardial contractility and that tumour necrosis factor- $\alpha$ plays an important part in the pathogenesis of myocardial injury in animal models of viral and autoimmune myocarditis.
\end{abstract}

Methods-Plasma interleukin 1- $a$, interleukin 1- $\beta$, interleukin-2, interleukin-6, tumour necrosis factor- $a$, tumour necrosis factor- $\beta$, granulocyte-macrophage colony stimulating factor, granulocyte colony stimulating factor, macrophage colony stimulating factor, interferon-a and interferon- $\gamma$ were measured in 13 patients with acute myocarditis, 23 patients with dilated cardiomyopathy, 51 patients with hypertrophic cardiomyopathy, nine patients with acute myocardial infarction, 18 patients with angina pectoris, 12 patients with essential hypertension and 17 healthy controls.

Results-Increased concentrations of cytokines were not detected in the controls. In patients with acute myocarditis, interleukin 1- $\alpha$ was detected in $23 \%$ (mean (SD) 25 (11) pg/ml), interleukin 1- $\beta$ in $31 \%$ (56 (34) $\mathrm{pg} / \mathrm{ml})$, tumour necrosis factor $-\alpha$ in $46 \%$ (61 (31) $\mathrm{pg} / \mathrm{ml})$, and macrophage colony stimulating factor was $2.5(1.8) \mathrm{ng} / \mathrm{ml}$ (normal $1.9(0.4))$. In patients with dilated cardiomyopathy, tumour necrosis factor-a was detected in $35 \%(402(555) \mathrm{pg} / \mathrm{ml})$. In patients with hypertrophic cardiomyopathy, interleukin-2 was detectable in 14\% (2318 (4738) $\mathrm{pg} / \mathrm{ml}$ ) and tumour necrosis factor- $a$ was detected in 20\% (992 (1517) $\mathrm{pg} / \mathrm{ml})$. The concentration of macrophage colony stimulating factor was raised in patients with acute myocardial infarction. Granulocyte colony stimulating factor was often increased in myocarditis, cardiomyopathies, acute myocardial infarction, and angina pectoris-suggesting activation of macrophages and/or endothelial cells-but this increase was not specific to these diseases. Increased concentrations of cytokines were not found in patients with essential hypertension.

Conclusion-These results suggest that cytokines may play a part in the pathogenesis of myocardial injury in myocarditis and cardiomyopathies and that further studies to explore the potential pathogenetic role of cytokines in myocardial diseases may be warranted.

(Br Heart $\mathcal{F} 1994 ; 72: 561-566)$

Cytokines are being increasingly recognised as essential mediators of normal and pathological immune responses. It is widely accepted that cytokines are involved in the cascade of events that lead to the wide range of biological responses to exogenous and endogenous pathogens.

A raised concentration of tumour necrosis factor- $a$ has been reported in some patients with acute myocardial infarction. ${ }^{1}$ Patients with chronic heart failure were also found to have high concentrations of tumour necrosis factor- $a$, but some cachectic patients did not. ${ }^{23}$ Tumour necrosis factor- $\alpha$ is also reported to depress myocardial contractility, alter muscle membrane potential, lower blood pressure, and precipitate pulmonary oedema. ${ }^{4-6}$

A recent experimental study showed the importance of interleukin-1 and tumour necrosis factor- $a$ in the pathogenesis of acute viral and autoimmune myocarditis. ${ }^{78}$ In a study of viral myocarditis in mice, circulating tumour necrosis factor- $a$ was raised in the acute stage, and exogenously administered tumour necrosis factor- $a$ exacerbated the myocarditis. Anti-tumour necrosis factor- $a$ antibody prevented the development of myocarditis. This experimental evidence suggests that tumour necrosis factor- $a$ may play an important part in the pathogenesis of myocardial injury in viral and autoimmune myocarditis. However, circulating concentrations of various cytokines have not been measured in patients with cardiomyopathy or myocarditis. The present study was designed to assess the potential role of cytokines in acute myocarditis, dilated cardiomyopathy, and hypertrophic cardiomyopathy.

\section{Patients and methods}

PATIENTS

We studied 13 patients with acute myocarditis, 23 patients with dilated cardiomyopathy, and 51 patients with hypertrophic cardiomyopathy who were admitted to our hospital between February 1987 and September 1991. We also studied 18 patients with angina pectoris and nine patients with acute myocardial infarction who were admitted to our hospital \\ The Third Divis
Department of
}


Table 1 Data on patients

\begin{tabular}{lccclll}
\hline & & & & \multicolumn{2}{l}{ Age $(y r)$} \\
\cline { 5 - 6 } & No & Male & Female & Mean $(S D)$ & Range \\
\hline Acute myocarditis & 13 & 9 & 4 & $38(20)$ & $19-72$ \\
Dilated cardiomyopathy & 23 & 19 & 4 & $57(15)$ & $18-76$ \\
Hypertrophic cardiomyopathy & 51 & 34 & 17 & $54(10)$ & $31-78$ \\
Acute myocardial infarction & 9 & 8 & 1 & $62(12)$ & $40-76$ \\
Angina pectoris & 18 & 12 & 6 & $64(10)$ & $49-77$ \\
Essential hypertension & 12 & 8 & 4 & $64(9)$ & $44-78$ \\
Healthy volunteers & 17 & 14 & 3 & $40(11)$ & $32-67$ \\
\hline
\end{tabular}

between March and October 1991. Twelve patients with essential hypertension (diastolic blood pressure $>90 \mathrm{~mm} \mathrm{Hg}$ ) and 17 healthy volunteers were also studied (table 1 ). The protocol was approved by the human research committee of our hospital. $M$ mode and cross sectional echocardiography were performed in all patients with acute myocarditis and cardiomyopathy.

Patients with acute myocarditis had a flulike illness, increased serum transaminase indicating an acute inflammatory reaction, and fulfilled the diagnostic criteria for myocarditis. ${ }^{9}$ The thickness of the interventricular septum and the left ventricular posterior wall was measured at the level of the anterior and posterior leaflets of the mitral valve. All patients with acute myocarditis and cardiomyopathy are consecutive and had right and left heart catheterisation, endomyocardial biopsy, and normal coronary arteries by selective coronary artery cineangiography. Criteria for selection of the patients with acute myocardial infarction were precordial chest pain typical of cardiac ischaemia lasting at least 30 minutes, ST elevation of at least $0 \cdot 1$ $\mathrm{mV}$ in two or more leads of the ECG with subsequent evolution of an ECG infarct pattern, and increased serum creatine kinase. All patients with acute myocardial infarction had routine cardiac catheterisation.

\section{Methods}

\section{CYTOKINE ASSAY}

Blood was collected at the time of diagnostic cardiac catheterisation in patients with acute myocarditis, cardiomyopathy, angina pectoris, and acute myocardial infarction. The patients had remained supine for at least 30 minutes in a quiet room. A $10 \mathrm{ml}$ sample of blood was taken into a chilled tube with $10 \mathrm{mg}$ of sodium ethylenediamine tetra-acetate. The sample was centrifuged immediately at $4^{\circ} \mathrm{C}$ and the separated plasma was stored at $-80^{\circ} \mathrm{C}$ until assay. Samples from the patients with acute myocarditis were collected within 7 days of the onset of the disease and those from the patients with acute myocardial infarction were obtained within 24 hours after the onset of the disease.

Interleukin- $1 \alpha$, interleukin- $1 \beta$, interleukin2 , interleukin-6, tumour necrosis factor- $\alpha$, tumour necrosis factor- $\beta$, granulocytemacrophage colony stimulating factor, granulocyte colony stimulating factor, interferon- $a$, and interferon- $\gamma$ were measured by enzyme linked immunoadsorbent assay. Macrophage colony stimulating factor was measured by radioimmunoassay. Cytokines were measured with commercial kits and kits originally developed by the Otsuka Pharmaceutical Company, Tokushima, Japan, according to the manufacturer's protocols. The sensitivity of the kits for each cytokine was $10 \mathrm{pg} / \mathrm{ml}$ for interleukin- $1 a, 20 \mathrm{pg} / \mathrm{ml}$ for interleukin- $\beta$, $78 \mathrm{pg} / \mathrm{ml}$ for interleukin-2, $32 \mathrm{pg} / \mathrm{ml}$ for interleukin-6, $20 \mathrm{pg} / \mathrm{ml}$ for tumour necrosis factor- $\alpha, 1 \mathrm{U} / \mathrm{ml}$ for tumour necrosis factor- $\beta$, $20 \mathrm{pg} / \mathrm{ml}$ for granulocyte-macrophage colony stimulating factor, $10 \mathrm{pg} / \mathrm{ml}$ for granulocytemacrophage colony stimulating factor, $0 \cdot 2$ $\mathrm{ng} / \mathrm{ml}$ for macrophage colony stimulating factor, $100 \mathrm{pg} / \mathrm{ml}$ for interferon- $a$, and $10 \mathrm{pg} / \mathrm{ml}$ for interferon- $\gamma$. Samples were run in duplicate, and to calculate the cytokine concentrations recombiant standards were inoculated on every plate. These kits detect natural cytokines and are not affected by the presence of soluble receptors. Results are given as mean (1SD).

\section{DATA ANALYSIS}

Frequencies of positive plasma in patients and controls were compared by a $\chi^{2}$ test. Data on macrophage colony stimulating factor were compared by an analysis of variance. The clinical variables in patients with detectable or undetectable tumour necrosis factor- $a$ were compared by Student's $t$ test. The correlation between clinical variables in each group of patients with cytokine concentration was analysed by linear regression.

\section{Results}

INTERLEUKINS

In the controls interleukin- $1 a$, interleukin- $1 \beta$, interleukin-2, interleukin-6, tumour necrosis factor- $a$, tumour necrosis factor- $\beta$, granulocyte colony stimulating factor, interferon- $\alpha$, and interferon- $\gamma$ were below the threshold of detection of our method and macrophage colony stimulating factor was $1.9(0.4) \mathrm{ng} / \mathrm{ml} \delta$ (mean (1SD)). Interleukin-1 $a$ was detected in plasma from three $(23 \cdot 1 \%)$ of 13 (25 (11) 을 $\mathrm{pg} / \mathrm{ml}$ ) patients with acute myocarditis, in 1 ) $(4.3 \%)$ of $23(14 \mathrm{pg} / \mathrm{ml})$ patients with dilated cardiomyopathy, and $4(7 \cdot 8 \%)$ of 51 (38 (15) N $\mathrm{pg} / \mathrm{ml}$ ) patients with hypertrophic cardiomy- N opathy (table 2 ). Interleukin- $1 \beta$ was detected 옹 in $30.8 \%(56(34) \mathrm{pg} / \mathrm{ml})$ of patients with acute myocarditis. Detectable concentrations of interleukin-1 $\alpha$ and interleukin-1 $\beta$ were more common in patients with acute $\stackrel{\oplus}{+}$ myocarditis than in controls. Interleukin-2 0 was detected in $13 \cdot 7 \%(2318(4738) \mathrm{pg} / \mathrm{ml})$ 응 of the patients with hypertrophic cardiomy- $\stackrel{\mathbb{\Omega}}{\bigcirc}$ opathy and was more commonly found in this $\stackrel{\mathbb{Q}}{\Omega}$ group than in patients with acute myocarditis or dilated cardiomyopathy, but the difference was not statistically significant. Interleukin- 6 응 was not often detected in patients with acute myocarditis or cardiomyopathy.

TUMOUR NECROSIS FACTOR- $a$

Tumour necrosis factor- $a$ was detected in six $(46 \cdot 1 \%)(61(31) \mathrm{pg} / \mathrm{ml})$ patients with acute 
Table 2 Frequency of detectable plasma cytokines in cardiac patients (mean (SD) of detectable values, pg/ml except for tumour necrosis factor- $\beta$ and macrophage colony stimulating factor)

\begin{tabular}{|c|c|c|c|c|c|c|c|c|}
\hline & $\begin{array}{l}\text { Acute } \\
\text { myocarditis } \\
(n=13)\end{array}$ & $\begin{array}{l}\text { Dilated } \\
\text { cardiomyopathy } \\
(n=23)\end{array}$ & $\begin{array}{l}\text { Hypertrophic } \\
\text { cardiomyopathy } \\
(n=51)\end{array}$ & $\begin{array}{l}\text { Acute } \\
\text { myocardial } \\
\text { infarction } \\
(n=9)\end{array}$ & $\begin{array}{l}\text { Angina } \\
\text { pectoris } \\
(n=18)\end{array}$ & $\begin{array}{l}\text { Essential } \\
\text { hypertension } \\
(n=12)\end{array}$ & $\begin{array}{l}\text { Healthy } \\
\text { volunteers } \\
(n=17)\end{array}$ & $\begin{array}{l}\text { Detectable } \\
\text { concentration }\end{array}$ \\
\hline Interleukin-1 $a$ & $\begin{array}{l}23 \cdot 1 \%{ }^{\star} \\
(25(11))\end{array}$ & $\begin{array}{l}4 \cdot 3 \% \\
(14)\end{array}$ & $\begin{array}{l}7 \cdot 8 \% \\
(38(15))\end{array}$ & $0 \%$ & $\begin{array}{l}11 \cdot 1 \% \\
(31)\end{array}$ & $0 \%$ & $0 \%$ & $>10 \mathrm{pg} / \mathrm{ml}$ \\
\hline Interleukin-1 $\beta$ & $\begin{array}{l}30 \cdot 8 \%^{*} \dagger \\
(56(34))\end{array}$ & $0 \%$ & $\begin{array}{l}9.8 \% \\
(96(68))\end{array}$ & $0 \%$ & $0 \%$ & $0 \%$ & $0 \%$ & $>20 \mathrm{pg} / \mathrm{ml}$ \\
\hline Interleukin-2 & $\begin{array}{l}7 \cdot 7 \% \\
(109)\end{array}$ & $\begin{array}{l}4 \cdot 3 \% \\
(301)\end{array}$ & $\begin{array}{l}13 \cdot 7 \% \\
(2318(4378))\end{array}$ & $0 \%$ & $0 \%$ & $0 \%$ & $0 \%$ & $>78 \mathrm{pg} / \mathrm{ml}$ \\
\hline Interleukin-6 & $\begin{array}{l}7 \cdot 7 \% \\
(145)\end{array}$ & $\begin{array}{l}4 \cdot 3 \% \\
(36)\end{array}$ & $\begin{array}{l}3.9 \% \\
(231(186))\end{array}$ & $0 \%$ & $0 \%$ & $0 \%$ & $0 \%$ & $>32 \mathrm{pg} \cdot \mathrm{ml}$ \\
\hline Tumour necrosis factor- $a$ & $\begin{array}{l}46 \cdot 1 \%{ }^{\star} \ddagger \\
(61(31))\end{array}$ & $\begin{array}{l}30 \cdot 4 \%^{\star} \\
(402(555))\end{array}$ & $\begin{array}{l}19 \cdot 6 \% \star \\
(992(1517))\end{array}$ & $\begin{array}{l}11 \cdot 1 \% \\
(113)\end{array}$ & $\begin{array}{l}16 \cdot 7 \% \\
(146(159))\end{array}$ & $0 \%$ & $0 \%$ & $>20 \mathrm{pg} / \mathrm{ml}$ \\
\hline $\begin{array}{l}\text { Tumour necrosis factor- } \beta \\
(\mathrm{U} / \mathrm{ml})\end{array}$ & $\begin{array}{l}7 \cdot 7 \% \\
(2 \cdot 2)\end{array}$ & $\begin{array}{l}4 \cdot 3 \% \\
(1 \cdot 8)\end{array}$ & $\begin{array}{l}3.9 \% \\
(1.7(0.8))\end{array}$ & $0 \%$ & $0 \%$ & $0 \%$ & $0 \%$ & $>1 \mathrm{U} / \mathrm{ml}$ \\
\hline $\begin{array}{l}\text { Granulocyte macrophage } \\
\text { colony stimulating factor }\end{array}$ & $\begin{array}{l}7 \cdot 7 \% \\
(100)\end{array}$ & $\begin{array}{l}4 \cdot 3 \% \\
(29)\end{array}$ & $\begin{array}{l}9 \cdot 8 \% \\
(92(16))\end{array}$ & $\begin{array}{l}11 \cdot 1 \\
(102)\end{array}$ & $\begin{array}{l}5 \cdot 5 \% \\
(164)\end{array}$ & $\begin{array}{l}8 \cdot 3 \% \\
(50)\end{array}$ & $0 \%$ & $>20 \mathrm{pg} / \mathrm{ml}$ \\
\hline $\begin{array}{l}\text { Granulocyte } \\
\text { colony stimulating factor }\end{array}$ & $\begin{array}{l}46 \cdot 1 \%{ }^{\star} \\
(18(10))\end{array}$ & $\begin{array}{l}65 \cdot 2 \% \star \\
(28(30))\end{array}$ & $\begin{array}{l}58 \cdot 8 \%^{\star} \\
(37(89))\end{array}$ & $\begin{array}{l}22 \cdot 2 \%^{\star} \\
(20(11))\end{array}$ & $\begin{array}{l}44 \cdot 4 \%{ }^{\star} \\
(38(48))\end{array}$ & $\begin{array}{l}8 \cdot 3 \% \\
(84)\end{array}$ & $\begin{array}{l}5 \cdot 9 \% \\
(13)\end{array}$ & $>10 \mathrm{pg} / \mathrm{ml}$ \\
\hline $\begin{array}{l}\text { colony stimulating factor }(\mathrm{ng} / \mathrm{ml}) \\
\text { Interferon- } a\end{array}$ & $\begin{array}{l}2 \cdot 5 \dagger \\
(1 \cdot 8) \\
7 \cdot 7 \% \\
(171)\end{array}$ & $\begin{array}{l}1 \cdot 5 \\
(0 \cdot 4) \\
0 \%\end{array}$ & $\begin{array}{l}1.9 \\
(0.4) \\
3.9 \% \\
(447(474)\end{array}$ & $\begin{array}{l}3 \cdot 3^{\star} \dagger \ddagger \\
(1 \cdot 1) \\
0 \%\end{array}$ & $\begin{array}{l}2 \cdot 4 \\
(0 \cdot 9) \\
0 \%\end{array}$ & $\begin{array}{l}14 \\
(0 \cdot 4) \\
0 \%\end{array}$ & $\begin{array}{l}1 \cdot 9 \\
(0 \cdot 4) \\
0 \%\end{array}$ & $\begin{array}{l}>0.2 \mathrm{~g} / \mathrm{ml} \\
>100 \mathrm{pg} / \mathrm{ml}\end{array}$ \\
\hline Interferon- $\gamma$ & $\begin{array}{l}7 \cdot 7 \% \\
(18)\end{array}$ & $\begin{array}{l}4 \cdot 3 \% \\
(19)\end{array}$ & $\begin{array}{l}3.9 \% \\
(34(11))\end{array}$ & $0 \%$ & $\begin{array}{l}5 \cdot 5 \% \\
(21)\end{array}$ & $0 \%$ & $0 \%$ & $>10 \mathrm{pg} / \mathrm{ml}$ \\
\hline
\end{tabular}

$\star \mathrm{P}<0.05 v$ healthy volunteers; $\dagger \mathrm{P}<0.05 v$ dilated cardiomyopathy; $\ddagger \mathrm{P}<0.05 v$ hypertrophic cardiomyopathy.

Concentrations of macrophage colony stimulating factor were above the detectable value in all individuals.

myocarditis, in seven $(30 \cdot 4 \%)(402(555)$ $\mathrm{pg} / \mathrm{ml}$ ) with dilated cardiomyopathy, in 10 $(19 \cdot 6 \%)(992(1517) \mathrm{pg} / \mathrm{ml})$ with hypertrophic cardiomyopathy, in one $(11 \cdot 1 \%)(113$ $\mathrm{pg} / \mathrm{ml}$ ) with acute myocardial infarction, and in three $(16.7 \%)(146(159) \mathrm{pg} / \mathrm{ml})$ with angina pectoris. It was not detected in plasma from any of the patients with essential hypertension or from normal volunteers. An increased concentration of tumour necrosis factor- $a$ was most commonly seen in acute myocarditis. High values were also seen in dilated or hypertrophic cardiomyopathy (fig 1). An extremely high concentration of tumour necrosis factor- $a$ (more than 1000 $\mathrm{pg} / \mathrm{ml}$ ) was seen in a patient with dilated cardiomyopathy with poor systolic function and congestive heart failure. The severity of congestive heart failure, however, was not always correlated with plasma concentrations of tumour necrosis factor in these subgroups. The concentration of tumour necrosis factor- $a$ was very high $(>1000 \mathrm{pg} / \mathrm{ml})$ in four patients with hypertrophic cardiomyopathy. Nonetheless tumour necrosis factor- $a$ was not increased in five patients with hypertrophic cardiomyopathy in whom a dilated ventricle and poor systolic function developed.

\section{COLONY STIMULATING FACTORS}

Tumour necrosis factor- $\beta$ or granulocytemacrophage colony stimulating factor was detected in only a few of these patients. Granulocyte colony stimulating factor was commonly increased in patients with myocarditis or cardiomyopathy, but no significant differences in frequency were found between the various groups. Raised concentrations of granulocyte colony stimulating factor were not correlated with numbers of leucocytes (data not shown).

Macrophage colony stimulating factor in normal volunteers was $1.9 \quad(0.4) \mathrm{ng} / \mathrm{ml}$. Plasma concentrations of macrophage colony-
Plasma tumour necrosis factor-a in patients with acute myocarditis, dilated cardiomyopathy, hypertrophic cardiomyopathy, and other cardiac diseases. Plasma concentrations of tumour necrosis factor- $\alpha$ were more frequently raised in acute myocarditis than in the other groups, but the values were higher in patients with dilated cardiomyopathy or hypertrophic cardiomyopathy.

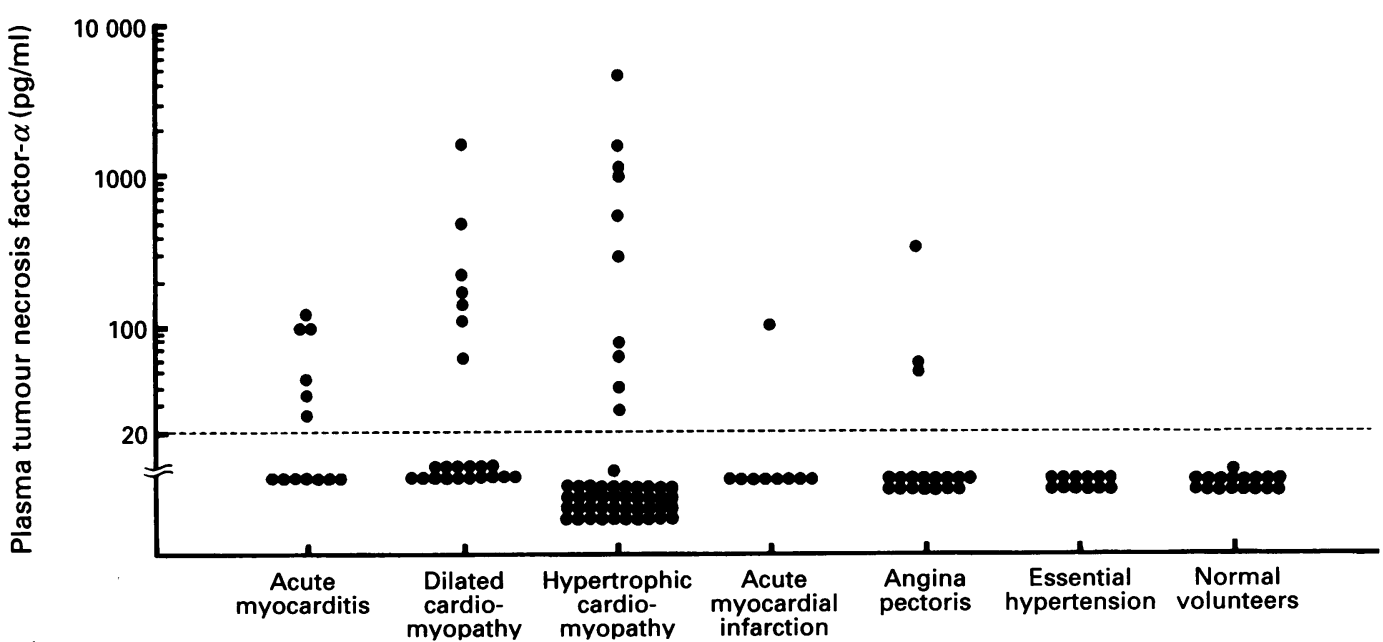


stimulating factor were $2.5(1.8) \mathrm{ng} / \mathrm{ml}$ in patients with acute myocarditis, $1.5(0.4)$ $\mathrm{ng} / \mathrm{ml}$ in patients with dilated cardiomyopathy, $1.9(0.8) \mathrm{ng} / \mathrm{ml}$ in patients with hypertrophic cardiomyopathy, $3.3(1 \cdot 1) \mathrm{ng} / \mathrm{ml}$ in patients with acute myocardial infarction, $2 \cdot 4$ $(0.9) \mathrm{ng} / \mathrm{ml}$ in patients with angina pectoris and $1.4(0.4) \mathrm{ng} / \mathrm{ml}$ in patients with essential hypertension. The concentration of macrophage colony stimulating factor was significantly higher in patients with acute myocarditis and acute myocardial infarction than in those with dilated cardiomyopathy, and the increase was most prominent in those with acute myocardial infarction. Granulocyte-macrophage colony stimulating factor, interferon- $a$, or interferon- $\gamma$ was uncommonly detected.

Thus, concentrations of inflammatory cytokines such as interleukin-1 $a$, interleukin$1 \beta$, and tumour necrosis factor- $a$ were increased in patients with acute myocarditis. In addition, tumour necrosis factor- $a$ was increased in patients with dilated cardiomyopathy and hypertrophic cardiomyopathy.

\section{Discussion}

Cytokines can be measured in plasma by sensitive and specific immunoradiometric and immunoenzymatic assays. Interleukin- 1 is a potent cytokine with broad proinflammatory activities. ${ }^{10}$ Like tumour necrosis factor, it is thought to play a central part in stimulating immune and inflammatory processes in response to microbial infection and tissue injury. Although most of the activities of interleukin-1 appear to favour tissue repair, when it is produced in high concentrations it can upset normal homoeostasis and exacerbate tissue injury. ${ }^{11}$ Interleukin-2 hypersecretion is a primary autosomal dominant trait that predisposes to the development of organ-specific autoimmunity. ${ }^{1213}$ In our study interleukin-2 was more commonly found in increased concentration in patients with hypertrophic cardiomyopathy. This difference was not statistically significant.

TUMOUR NECROSIS FACTOR- $a$ AND THE HEART The concentration of tumour necrosis factor- $a$ was reported to be raised in five of 22 patients with acute myocardial infarction and these patients had large infarcts complicated by hypotension and pulmonary oedema. ${ }^{1}$ In our study, however, a raised concentration of tumour necrosis factor- $a$ was uncommon in patients with acute myocardial infarction. When the patients with or without raised concentrations of tumour necrosis factor- $a$ in each group were compared with respect to body weight, blood pressure, heart rate, serum C-reactive protein, serum creatine kinase, glutamic oxaloacetic transaminase, blood urea nitrogen, echocardiographic variables, pulmonary capillary wedge pressure, left ventricular end diastolic pressure, and cardiac index, no significant differences were found (data not shown). Tumour necrosis factor- $a$ has been reported to depress myocar- dial contractility, alter muscle membrane potential, lower blood pressure, and precipitate pulmonary oedema. ${ }^{4-6}$ Repeated infusions of tumour necrosis factor can lead to a permanent decrease in myocardial contractility and ultimately dilated cardiomyopathy. ${ }^{14}$

\section{IMPORTANCE OF CYTOKINES IN THE}

PATHOGENESIS OF MYOCARDITIS

A recent experimental study showed that administration of interleukin-1 or tumour necrosis factor- $a$ promoted coxsackievirus B3 myocarditis in genetically resistant B10A mice. $^{7}$ In an experimental model of myocarditis caused by the encephalomyocarditis virus in mice, exogenously administered recombinant human tumour necrosis factor- $a$ increased the virus concentration in the myocardium, produced myocardial necrosis and cellular infiltration, and exacerbated myocarditis. When antibody to tumour necrosis factor $a$ antibody was given survival and myocardial lesions improved. ${ }^{8}$ In this model, circulating tumour necrosis factor- $a$ was increased in the acute stage ${ }^{8}$ and antiheart antibody was found in the serum, suggesting that autoimmunity may cause myocardial dysfunction. ${ }^{15}$ Antibody against tumour necrosis factor- $\alpha$ also had a beneficial effect in myosininduced autoimmune myocarditis. ${ }^{16}$ Evidence from these studies suggests that tumour necrosis factor- $\alpha$ may play an important part in the pathogenesis of myocardial injury in viral and autoimmune myocarditis. In addition to the animal models, a recent study showed that coxsackievirus B3 induced production of tumour necrosis factor- $a$, interleukin-1 $\beta$, and interleukin-6 in human monocytes in vitro. ${ }^{17}$ In our study, increased circulating interleukin-1 $a$, interleukin-1 $\beta$, interleukin-6, and tumour necrosis factor- $a$, the so-called inflammatory cytokines, were found in some patients with acute myocarditis. Various agents cause acute myocarditis but the most important cause is virus infection. Tumour necrosis factor- $\alpha$ is sometimes increased in patients with dilated cardiomyopathy, though less frequently. The most important cause of dilated cardiomyopathy is now believed to be viral myocarditis. ${ }^{18} 19$ Various immunological abnormalities have been reported in patients with dilated cardiomyopathy including the appearance of anti-heart autoantibodies ${ }^{20-22}$ and abnormal natural killer cell or $T$ lymphocytes. ${ }^{23} 24$ Possibly these immunological abnormalities are associated with previous viral infection and increased production of cytokines. Although there was no clear correlation between clinical variables and an increased concentration of tumour necrosis factor- $\alpha$ or other cytokines, cytokines could be independent markers of the immunological state in patients with cardiomyopathies and myocarditis.

CYTOKINES DEPRESS MYOCARDIAL

CONTRACTILITY

Tumour necrosis factor- $a$, interleukin- 6 , and interleukin- 2 inhibited the contractility of 
isolated hamster papillary muscles in a concentration-dependent, reversible manner. The nitric oxide synthase inhibitor, NGmonomethyl-L-arginine, blocked these negative inotropic effects. L-Arginine reversed the inhibition by NG-monomethyl-L-arginine. These findings show that the direct negative inotropic effect of cytokines is mediated through a myocardial nitric oxide synthase. ${ }^{25}$ The contractile response of cultured rat ventricular myocytes to a $\beta$ adrenergic agonist was depressed by a soluble inflammatory mediator produced by induction of an autocrine nitric oxide signalling pathway. ${ }^{26} 27$ The regulation of pro-inflammatory cytokines and myocardial nitric oxide synthase may provide new therapeutic strategies for the treatment of cardiac diseases. In vitro work showed that tumour necrosis factor- $a$ (150-3200 U/ml) had a detrimental cardiovascular effect. ${ }^{25}$ Because tumour necrosis factor- $a$ has a biological activity of 20-50 U/pg, the concentrations of these cytokines detected in patients seem to be high enough to produce a biological effect.

\section{TUMOUR NECROSIS FACTOR- $a$ AND MAJOR HISTOCOMPATIBILITY COMPLEX}

The genes encoding tumour necrosis factor- $a$ and tumour necrosis factor- $\beta$ are situated within the major histocompatibility complex locus. Familial hypertrophic cardiomyopathy has been shown to be associated with HLADR4 and with other major histocompatibility complex haplotypes. ${ }^{28}{ }^{29}$ Dilated cardiomyopathy too was reported to be associated with HLA-DR4 and HLA-DQw4. ${ }^{30}$ Thus, raised concentrations of plasma tumour necrosis factor- $\alpha$ in patients with hypertrophic and dilated cardiomyopathy may be associated with a major histocompatibility complex.

Molecular genetic studies showed that mutations within the $\beta$ cardiac myosin heavy chain gene cause hypertrophic cardiomyopathy in some families. ${ }^{31}$ In most of clinically affected individuals, however, a disease-causing mutation has not been identified. ${ }^{32}$ There are only a few reports of an immunological abnormality in hypertrophic cardiomyopathy, but the raised concentrations of cytokines that we detected suggest that an immunological mechanism may be involved in its pathogenesis. In addition we found a high frequency of anti-heart autoantibody in patients with hypertrophic cardiomyopathy (unpublished observation).

\section{SIGNIFICANCE OF RAISED CONCENTRATIONS OF} COLONY-STIMULATING FACTOR

Granulocyte colony stimulating factor seems to be produced constitutively, and steadystate and stimulated concentrations of granulocyte colony stimulating factor circulate in the plasma. ${ }^{33}$ Interleukin-1 and tumour necrosis factor induce the production of granulocyte colony stimulating factor by endothelial cells, fibroblasts, and bone marrow stromal cells. ${ }^{34}$ Granulocyte colony stimulating factor was detected more often than normal in all the groups in this study and this may suggest activation of macrophages and/or endothelial cells; none the less the increase was not specific to the diseases. Although the healthy volunteers were significantly younger than all other groups of patients except for those with myocarditis, the patients with essential hypertension, being older, serve as an appropriate control for the patients with myocardial disease. Macrophage colony stimulating factor is also produced by various cell types, including $\mathrm{T}$ cell, ${ }^{35}$ and can be elaborated by macrophages or monocytes during adherence and differentiation. Macrophage colony stimulating factor can also induce several other cytokines including interleukin-1 and granulocyte colony stimulating factor and thus upregulate its own synthesis. In this study the increased concentration of macrophage colony stimulating factor in acute myocarditis and acute myocardial infarction may reflect acute damage of cardiac myocytes.

Raised concentrations of plasma cytokines in selected patients may be the consequence of $(a)$ ongoing immune reaction perpetuating a primary cardiac injury; (b) a general response to cardiac injury of other cause; $(c)$ immune activation resulting from systemic circulatory disturbances such as tissue hypoxia or congestion; or $(d)$ the consequence of neuroendocrine responses to cardiac dysfunction such as sympathetic activation or activation of other neuroendocrine pathways. Further studies are necessary to clarify the pathophysiological role of the cytokines in myocardial disease.

\section{CONCLUSIONS}

Plasma concentrations of interleukin-1 $\alpha$, interleukin- $1 \beta$, and tumour necrosis factor- $a$ were increased in patients with acute myocarditis. Tumour necrosis factor- $a$ was also increased in dilated cardiomyopathy and hypertrophic cardiomyopathy. These results suggest that cytokines may play an important part in the pathogenesis of myocardial injury in cardiomyopathy and myocarditis and that the potential pathogenetic role of cytokines in myocardial diseases should be explored in further studies.

This work was supported, in part, by a research grant from the Ministry of Health and Welfare and by a grant in aid for developmental research and general scientific research from the Ministry of Education, Science and Culture, and the Kanazawa Research Fund, Japan.

We thank Dr N Tomioka, Dr I Okada, Dr M Tominaga, Dr A Tanaka, Dr T Hirozane, Dr S Maruyama, Dr S Morishima, Dr B Kyu, Dr Y Sato, Dr T Shioi, Dr S Matsui, Dr M Dr B Kyu, Dr Y Sato, Dr T Shioi, Dr S Matsui, Dr M Kawhida for helping with this work and Mr Y Ohmoto and Mr H Toriyama for assistance with the cytokine assays.

1 Maury CP, Teppo A-M. Circulating tumor necrosis factor- $\alpha$ (cachectin) in myocardial infarction. $\mathcal{F}$ Int Med 1989;225:333-6.

2 Levine B, Kalman J, Mayer L, Fillit HM, Packer M. Elevated circulating levels of tumor necrosis factor in severe chronic heart failure. $N$ Engl 7 Med 1990; 323:236-41.

3 McMurray J, Abdullah I, Dargie HJ, Shapiro D. Increased concentrations of tumour necrosis factor in "cachectic" patients with severe chronic heart failure. Br Heart $\mathrm{f}$ patients with se

4 Hocking DC, Phillips PG, Ferro TJ, Johnson A. Mechanisms of pulmonary edema induced by tumor necrosis factor- $\alpha$. Circ Res 1990;67:68-77. 
5 Tracey KJ, Lowry SF, Beutler B, Cerami A, Albert JD Shires GT. Cachectin/tumor necrosis factor mediates changes of skeletal muscle plasma membrane potential. f Exp Med 1986;164:1368-73.

6 Cunnion RE, Parillo JE. Myocardial dysfunction in sepsis. Chest 1989;95:941-5.

7 Lane JR, Neumann DA, Lafond-Walker A, Herskowitz A Rose NR. Interleukin-1 or tumor necrosis factor can promote coxsackie B3-induced myocarditis in resistan B10.A mice. $₹$ Exp Med 1992;1 175:1 123-9.

8 Yamada T, Matsumori A, Sasayama S. Therapeutic effect of anti-tumor necrosis factor- $a$ antibody on the murine model of viral myocarditis induced by encephalomyocarditis virus. Circulation 1994;89:846-51.

9 Aretz HT, Billingham ME, Edwards WD, Factor SM, Fallon JT, Fenoglio JJ Jr, et al. Myocarditis: a histopathologic definition and classification. $A m$ f Cardiovasc Pathol 1986;1:3-14.

10 Fuhlbrigge RC, Hogquist KA, Unanue ER, Chaplin DD. Molecular biology and genetics of interleukin-1. In: Cruse JM, Lewis RE, eds. The year in immunology, vol 5. Basel: S Karger, 1989;21-37.

11 Dinarrello CA, Savage N. Interleukin-1 and its receptor. CRC Crit Rev Immunol 1989;9:1-20.

12 Kroemer G, Gastinel LN, Neu N, Auffray C, Wick G How many genes code for organ-specific autoimmunity? Autoimmunity 1990;6:215-33.

13 Kroemer G, Neu N, Faessler R, Kuehr T, Dietrick H, Fässler $\mathrm{R}$, et al. Immunogenetic analysis of spontaneous autoimmune thyroiditis of obese strain (OS) chickens with spontaneous autoimmune thyroiditis. Clin Immunol Immunopathol 1989;52:202-13.

14 Hegewisch SC, Weh H-J, Hossfeld DK. TNF-induced cardiomyopathy. Lancet 1990;ii:294-5.

15 Tominaga M, Matsumori A, Horie M, Yoshida H, Okada Y. Activation of Ca-permeable cation channels by myocarditis-associated antibody in guinea pig ventricular myocytes. $¥$ Clin Invest 1993;91:1231-4.

16 Smith SC, Allen PM. Neutralization of endogenous tumo necrosis factor ameliorates the severity of myosininduced myocarditis. Circ Res 1992;70:856-63.

17 Henke A, Mohr C, Sprenger H, Graebner C, Stelzner A Nain $M$, et al. Coxsakievirus B3-induced production of tumor necrosis factor- $a$, IL-1 $\beta$ and IL-6 in human monocytes. F Immunol 1992;148:2270-7.

18 Kawai C, Matsumori A, Fujiwara H. Myocarditis and dilated cardiomyopathy. Annu Rev Med 1987;38: 221-39.

19 Abelmann WH, Lorell $\mathrm{BH}$. The challenge of cardiomyopathy. F Am Coll Cardiol 1989;13:1219-39.

20 Schultheiss H-P. The significance of autoantibodies against the ADP/ATP carrier for the pathogenesis of myocarditis and dilated cardiomyopathy-clinical and experimental data. Springer Semin Immunopathol 1989; 11:15-30.

21 Maisch B. Retrospective and perspectives in the immunology of cardiac diseases. Springer Seminar Immunopathol 1989;11:479-82.
22 Caforio ALP, Grazzini M, Mann JM, Keeling PJ, Bottayyo GF, McKenna WJ, et al. Identification of $a$ - and $\beta$-cardiac myosin heavy chain isoforms as major autoantigens in dilated cardiomyopathy. Circulation 1992;85. $1734-42$.

23 Eckstein R, Mempez W, Bolte HD. Reduced suppressor cell activity in congestive cardiomyopathy and in cell activity in congestive cardiomyopathy and in

24 Anderson JL, Carlquist JF, Hammond EH. Deficient natural killer cell activity in patients with idiopathic dilated cardiomyopathy. Lancet 1982;ii: 1124-7.

25 Finkel MS, Oddis CV, Jacob TD, Watkins SC, Hattler BG, Simmons RL. Negative inotropic effects of cytokines on the heart mediated by nitric oxide. Science 1992;257:387-9.

26 Balligand J-L, Kelly RA, Marsden PA, Smith TW, Michel $T$. Control of cardiac muscle cell function by an endogenous nitric oxide signalling system. Proc Natl Acad $S_{C i}$ USA 1993;90:347-51.

27 Balligand J-L, Ungureanu D, Kelly RA, Kobzik L Pimental D, Michel T, et al. Abnormal contractile function due to induction of nitric oxide synthesis in rat cardiac myocyte follows exposure to activated diac myocyte follows exposure to activated macrophage

28 Matsumori A, Hirose $\mathrm{K}$, Wakabayashi A, Kawai C Nabeya N, Sakurami T, et al. HL-A and hypertrophic cardiomyopathy. Am Heart f 1979;97:428-31.

29 Matsumori A, Kawai C, Wakabayashi A, Terasaki PI, Park MS, Sakurami T, et al. HLA-DRW4 antigen linkage in patients with hypertrophic obstructive cardiomyopathy. Am Heart ₹ 1981;101:14-6.

30 Carlquist JF, Menlove RL, Murray MB, O'Connell JB, Anderson JL. HLA class II (DR and DQ) antigen associAnders in JL. HLA class II (DR and DQ antigen associations in idiopathic dila in (DR and DO antigen associstudy and meta-analysis of published

31 Geisterfer-Lowrance AAT, Kass S, Tanigawa G, Vosverg H-P, McKenna W, Seidman CE, et al. A molecular basis for familial hypertrophic cardiomyopathy: A $\beta$ cardiac myosin heavy chain gene missense mutation. Cell 1990;62:999-1006.

32 Watkins H, Rosenzweig A, Hwang D-S, Levi T, McKenna W, Seidman CE, et al. The location and prognostic implications of myosin missense mutations in familial hypertrophic cardiomyopathy. N Engl $7 \mathrm{Med} \mathrm{1992;}$ 326:1108-14.

33 Kawakami M, Tsutsumi H, Kumakawa T, Abe H, Hirai $M$, Kurosawa $S$, et al. Levels of serum granulocyte colony stimulating factor in patients with infections. Blood 1990;76:1962-4

34 Koeffker HP, Gasson J, Ranyard L, Souza L, Shephard M, Munker R. Recombinant human TNF- $a$ stimulates production of granulocyte colony-stimulating factor. Blood 1987;70:55-9.

35 Arya SK, Wong-Staal F, Gallo RC. T-cell growth factor gene: Lack of expression in human T-cell leukemia-lymphoma virus-infected cells. Science 1984;223:1086-7. 